\title{
The Civic Empowerment Gap: Defining the Problem and Locating Solutions
}

\section{Citation}

Levinson, Meira. 2010. The Civic Empowerment Gap: Defining the Problem and Locating Solutions. In Handbook of Research on Civic Engagement, ed. Lonnie Sherrod, Judith TorneyPurta, and Constance A. Flanagan, 331-361. Hoboken, NJ: John Wiley \& Sons.

\section{Permanent link}

http://nrs.harvard.edu/urn-3:HUL.InstRepos:8454069

\section{Terms of Use}

This article was downloaded from Harvard University's DASH repository, and is made available under the terms and conditions applicable to Other Posted Material, as set forth at http:// nrs.harvard.edu/urn-3:HUL.InstRepos:dash.current.terms-of-use\#LAA

\section{Share Your Story}

The Harvard community has made this article openly available.

Please share how this access benefits you. Submit a story. 


\section{Chapter 13}

The Civic Empowerment Gap: Defining the Problem and Locating SOLUTIONS

\section{MeIRA LeVINSON}

HARVARD UNIVERSITY

Final submitted ms [pre-page proof edits] for:

Handbook of Research on Civic Engagement in Youth (2010). Lonnie Sherrod, Judith Torney-Purta \& Constance A. Flanagan (Eds.) NY: John Wiley and Sons. 978-0-470-522274-5 
The purpose of this chapter is to demonstrate that there is a profound civic empowerment gap in the United States - as large and as disturbing as the nationally recognized reading and math achievement gaps - and to argue that schools can and should help address this gap. There is widespread recognition that political power is distributed in vastly unequal ways among U.S. citizens. As the American Political Science Association's Task Force on Inequality and American Democracy memorably put it, "Citizens with low or moderate incomes speak with a whisper that is lost on the ears of inattentive government, while the advantaged roar with the clarity and consistency that policymakers readily heed" (APSA Task Force on Inequality and American Democracy, 2004, p. 651). Less poetically, but as powerfully, Bartels (2008) recently demonstrated that "political influence seems to be limited entirely to affluent and middle-class people. The opinions of millions of ordinary citizens in the bottom third of the income distribution have no discernible impact on the behavior of their elected representatives" (p. 5). Both scholars and educators can do much more to clarify the role of schools in contributing to and ameliorating this problem. The purpose of this chapter is to clarify the ways in which schools, understood both as contextually located civic institutions and as primary deliverers of civic education, can and must help address this unjust civic empowerment gap, especially among historically disenfranchised populations.

The first section begins by defining good citizenship, and by extension, the aims of good civic education. I then demonstrate the existence of a broad and deep civic empowerment gap across all dimensions of good citizenship - civic and political knowledge, skills, attitudes, and behaviors - and argue that this gap challenges the stability, legitimacy, and quality of our democratic republic. In the second section, I suggest that we focus on de facto segregated urban schools as crucial sites for addressing the civic empowerment gap. The third section then recommends five specific approaches that could improve access to high-quality civic education and experiences, especially among historically disenfranchised youth. These include reducing the dropout rate, improving the quantity and distribution of civic education across $\mathrm{K}-12$ education, engaging students in coconstructing empowering civic historical narratives, infusing experiential civic education throughout the curriculum, and providing powerful civic learning and engagement opportunities for urban teachers.

\section{Citizenship and the Civic Empowerment Gap}

What are the components of citizenship, and what does it mean to be a good citizen? These questions must be answered prior to any discussion about the aims or content of civic education. Can you be a good citizen if you don't vote? What if you vote, but are uninformed about most of the issues and candidates, or vote solely on the basis of a single issue? How important is it to be law-abiding? 
Is being economically self-sufficient a hallmark (or even a precondition) of good citizenship? How should we judge the act of protesting injustice via civil disobedience against the act of sacrificing oneself on the battlefield? Depending on how one answers these questions, one's judgment about what makes for good civic education will be radically different.

In this chapter, I adopt the definition set forth in The Civic Mission of Schools, as it integrates many disparate strands of belief and ideology about citizenship:

Civic education should help young people acquire and learn to use the skills, knowledge, and attitudes that will prepare them to be competent and responsible citizens throughout their lives. Competent and responsible citizens:

1. Are informed and thoughtful; have a grasp and an appreciation of history and the fundamental processes of American democracy; have an understanding and awareness of public and community issues; and have the ability to obtain information, think critically, and enter into dialogue among others with different perspectives.

2. Participate in their communities through membership in or contributions to organizations working to address an array of cultural, social, political, and religious interests and beliefs.

3. Act politically by having the skills, knowledge, and commitment needed to accomplish public purposes, such as group problem solving, public speaking, petitioning and protesting, and voting.

4. Have moral and civic virtues such as concern for the rights and welfare of others, social responsibility, tolerance and respect, and belief in the capacity to make a difference.

(Carnegie Corporation of New York \& CIRCLE, 2003, p. 4).

One virtue of this characterization of good citizenship, and hence of good civic education, is that it is capacious without being simplistic. Within this definition, good citizens may be those who vote, protest, boycott, run for office, join political parties, join civic organizations, commit acts of civil disobedience, circulate e-mail petitions, write influential political blogs, "tweet" or text message about political events being kept under a news blackout, and attend neighborhood council meetings. Good citizens may not, however, merely keep to themselves; simply not being a burden to others is not sufficient for good citizenship. In this respect, this definition rejects the ideal of the "personally responsible citizen," as Westheimer and Kahne describe in their influential article, "What Kind of Citizen" (Westheimer \& Kahne, 2004, p. 239), but encompasses their ideals of both "participatory" and "justice-oriented" citizens. Participatory citizens believe that "to solve social problems and improve society, citizens must actively participate and take leadership positions within established systems and community 
structures," while justice-oriented citizens believe that one must "question, debate, and change established systems and structures that reproduce patterns of injustice over time" (Westheimer \& Kahne, 2004, p. 240, Table 1). Participatory and justice-oriented citizens frequently disagree about the most fruitful acts to take as citizens - and hence also would disagree about the best approaches to citizenship education — but they both embrace the importance of knowledgeable, skillful, active involvement in civic and political institutions in order to improve society. The definition of good citizenship given above clearly would recognize both kinds of citizens as good citizens.

On the downside, this definition arguably privileges traditional modes of civic action that are both increasingly outdated and unrepresentative of a range of actions and behaviors that have historically been important civic tools of members of disadvantaged, oppressed, or marginalized groups, or any combination of the three. For example, various Web 2.0 activities such as uploading a video to YouTube and interacting through social networking sites such as Facebook or Ning do not obviously fit into the categories and actions described above, despite their increasingly evident civic importance (see Bennett, this volume). This definition also seems to exclude artistic production and expression such as hip-hop music and videos, poetry slams, and graffiti_all of which have arguably been used especially by young, often poor, people of color in the United States and elsewhere to critique contemporary power structures and civic institutions. Furthermore, it fails to credit the civic intentionality and implications of "everyday ... forms of resistance" by "relatively powerless groups: foot dragging, dissimulation, desertion, false compliance, pilfering, feigned ignorance, slander, arson, sabotage, and so on" (Scott, 1985, p. xvi). Finally, emphasis on public and collective forms of engagement likely overlooks the ways in which especially members of historically disadvantaged groups may be "pillars of their communities" without participating collectively in public activities. A wellknown community elder, for example, may exert considerable civic influence by modeling rectitude, advising youngsters about how to behave, and serving as an informal but final arbiter of community disputes, even though he takes part in no obvious "public" activities. These are all arguably significant civic roles, actions, and dimensions of influence that are not obviously included in the definition above.

It is nonetheless worth proceeding with this definition - and with the measures of civic engagement that follow from the definition-for a couple of reasons. First, we don't have good quantitative measures of most of the forms of civic engagement listed in the above paragraph. Scholars who study civic engagement in the United States have relatively good quantitative measures of rates of voting, government contact, political discussion in the home, boycotts, and even protest participation (among many others). But they don't have good measures of use of social networking tools for civic engagement, or of how civic 
engagement is expressed and enacted through art or music, hip-hop culture, informal neighborhood leadership, or calculated subversion. A more expansive definition would incorrectly suggest that my analysis of demographic measures of civic empowerment was capable similarly of being more expansive, which it is not. ${ }^{1}$ Second, traditional forms of engagement still matter with respect to empowerment. People who vote regularly, contact politicians and other government officials, speak up in public meetings, join civic organizations, and donate money to both candidates and civic causes almost invariably have more civic and political power in the United States in the early twenty-first century than those who do not. Since this chapter is about civic empowerment, we need to take these traditional measures of civic engagement into account, even at the cost of privileging them over other modes that are more accessible to and more frequently employed by members of historically disadvantaged groups. This risks creating a circular and apparently deficit-oriented argument in which I place certain groups at the bottom of a civic empowerment gap, precisely because I discount forms of civic engagement in which they are particularly involved. But gaps need not imply deficits, and it does no one any good to ignore the specific harms suffered by those who cannot or do not deploy traditional levers of civic and political power. Thus, I will rely upon this definition of good citizenship-and correlatively, of the desirable outcomes of good civic education-despite its acknowledged limitations.

Central to this definition are civic knowledge, skills, attitudes, and behaviors. Good citizens need to be knowledgeable about politics, history, government, and current events; they need to be skilled communicators, thinkers, deliberators, and actors; they need to be concerned about the common good in addition to their own self-interest, and to believe it is possible and worth trying to make a difference through public action; and they need to become involved in public or community affairs, through some combination of voting, protesting, contacting public officials, mobilizing others, contributing time or money to causes or campaigns, participating in community groups, and other appropriate actions. No matter where one lands on the participatory versus justice-oriented continuum, or on the civic versus political continuum (Zukin, Keeter, Andolina, Jenkins, \& Delli Carpini, 2006; Lopez, Levine, Both, Kiesa, Kirby, \& Marcelo, 2006)), these four attributes are necessary to be a good citizen. On all of these measures, there is evidence of a profound gap between many non-White, immigrant, and especially low-income youth and adults, on the one hand, and White, native-born, and especially middle-class or wealthy youth and adults, on the other (see Jensen, this volume; Seif, this volume).

\section{Knowledge and Skills}

\footnotetext{
${ }^{1}$ Qualitative data and research are obviously also crucial to documenting and understanding the multiple dimensions and patterns of civic engagement and empowerment.
} 
As early as in the 4th grade and continuing into the 8th and 12th grades, African-American, Hispanic, and poor students perform significantly worse on the National Assessment of Educational Progress' (NAEP) test of civic knowledge than White, Asian, and middle-class students (U.S. Department of Education, Institute of Education Sciences, National Center for Education Statistics, \& National Assessment of Educational Progress (NAEP), 2007; Lutkus, Weiss, Campbell, Mazzeo, \& Lazer, 1999). On the 2006 NAEP Civics Assessment, for example, White 4th and 8th graders who were poor (i.e., eligible for free or reduced-price lunch) performed as well as middle-class and wealthy (ineligible for free or reduced-price lunch) African-American and Hispanic students-and significantly better than poor African-American and Hispanic students. Asian students' results were mixed. Within each racial/ethnic group, poor students earned significantly lower scores than middle-class and wealthier students (computed using data from IES: National Center for Education Statistics, 2007). Similar disparities appear in American 9th graders' scores on the 1999 IEA test of civic knowledge and skills (Baldi, Perie, Skidmore, Greenberg, \& Hahn, 2001, Tables 4.1 and 4.5; Torney-Purta, Barber, \& Wilkenfeld, 2007). Immigration status also seems to influence students' mastery of civic knowledge and skills. Students who haven't lived in the United States their whole lives performed significantly worse on the 1998 NAEP Civics Assessment than students who have always done so, with scores directly related to the number of years living in the United States (IES: National Center for Education Statistics, 2007); similar results hold for 9th graders' performance on the IEA test (Torney-Purta, Barber, \& Wilkenfeld, 2007). This shouldn't be surprising, since it is predictable that the longer students live in the United States, the more they will learn about U.S. government and democracy. But it does set the stage for civic and political participation gaps between native-born and naturalized citizens, as I discuss below.

These results for youth are, unsurprisingly, echoed in studies of adults. In a comprehensive study of adults' civic and political knowledge, Delli Carpini and Keeter (1996) conclusively demonstrate that "men are more informed than women; whites are more informed than blacks; those with higher incomes are more informed than those with lower incomes; and older citizens are more informed than younger ones." These disparities are not small: out of the 68 questions asked in the 1989 Survey of Political Knowledge, for example, "In no case was the percentage correct for blacks as high as for whites or for low-income citizens as high as that for upper-income ones." Similarly, three-quarters of Black Americans scored below all but the bottom quarter of White Americans; more than three-quarters of poor respondents scored below the top three-quarters of their middle-class counterparts (Delli Carpini \& Keeter, 1996, p. 157, also Tables 4.8 and 4.9, Figure 4.1; see also Verba, Schlozman, \& Brady, 1995, Table 12.4; and The Pew Research Center for the People and the Press, 2007, for independent 
corroborating data). These patterns can manifest themselves in startling ways. In 2004, for example, when I was teaching eighth grade in a Boston public school that served predominantly low-income, first- and second-generation immigrant students of color, none of my 27 homeroom students knew that July 4th celebrates the signing and publication of the Declaration of Independence (see Hart \& Atkins, 2002, for a similar story).

It is undoubtedly true that these surveys and tests of political and civic knowledge and skills are both limited and biased in a number of ways. Relevant political and civic knowledge are defined overwhelmingly by middle-class, nativeborn, White scholars, educators, and policy makers, who care about federal and especially electoral politics. They privilege both modes and content of civic knowledge that are familiar to and valued by such groups. Thus, the 1989 and 2007 Pew Surveys of Political Knowledge, cited above, ask respondents to identify the Speaker of the House and other public officials, answer specific questions about impending federal legislation and policies, name foreign leaders, and answer questions about domestic and foreign affairs (The Pew Research Center for the People and the Press, 2007). Other political knowledge and skills are arguably of far greater relevance to many low-income youth of color living in urban neighborhoods. My eighth-grade students, for example, eloquently made the case that I-a White, middle-class woman living in a middle-class Boston neighborhood - would have a hard time understanding and negotiating the politics of "the hood" in which they lived. I certainly would have flunked a test that asked me to identify members of the locally relevant power structure: who controlled what block; which housing projects I could safely enter as a resident of another project; or which social workers, police officers, and housing authority representatives could be trusted and who were to be avoided (see, e.g., Ayers \& Ford, 1996).

Even independent of a race-, class-, or context-based analysis of what kinds of political knowledge matter, there is little agreement between those who design tests of students and those who design adult surveys about what kinds of civic knowledge count. As Niemi and Sanders (2004) point out, "NAEP quizzes students almost exclusively about political structures and institutions, whereas adult 'tests' focus mostly on contemporary politics (personalities and policies) ... raising questions about the meaningfulness of the items on which students are tested" (p. 327). They go on to conclude, "The kind of information routinely sought from students is simply not essential for them to have as adults" (p. 337).

Even if these measures of civic knowledge for adults or children are incomplete, skewed, and/or poorly justified, both the sheer lack of knowledge as well as the consistency of the differences matter and should be troubling. Traditionally measured civic knowledge is clearly and directly correlated with higher levels of political participation, and expression of democratic values including toleration, stable political attitudes, and adoption of "enlightened self- 
interest" (Galston, 2001; Delli Carpini \& Keeter, 1996). One's capacity for civic empowerment is greater if one knows about both political structures and institutions as well as about contemporary politics than if one does not know of these things. It is easy to imagine how people who don't know who their elected representatives are, what the White House's position is on various high-profile policy disputes, or how a bill becomes a law, may find it harder to influence civic life than those who do (Hart \& Atkins, 2002). These domains of knowledge aren't all that matter. But it would be hard to claim that they are irrelevant to the distribution of power in society. Thus, demographically predictable patterns in the distribution of knowledge in these domains presage a disturbing civic empowerment gap.

People who are poor and non-White are also demonstrably less likely to develop traditional civic skills via education, the workplace, or participation in voluntary associations - three of the primary venues in which individuals have the opportunity to develop and practice communication, analysis, organization, and leadership skills relevant to civic and political participation. This is because they are likely to leave school sooner, to have attended worse schools, to have lowerstatus jobs, and to participate less in voluntary associations. Churches may ameliorate, but certainly do not solve, this civic skills opportunity gap (Verba, Schlozman, \& Brady, 1995, chap. 11). Again, I contended almost daily with this gap as an urban middle-school teacher. My eighth-grade students frequently struggled to negotiate conflicts without getting into fights; they interacted ineffectually with authority figures and ended up in trouble despite their best intentions not to; and they relied on me to teach them even such basic skills as how to use a phone book and talk on the phone in a professional manner because they had never seen these skills modeled by others. Similarly, I frequently watched in frustration (and assisted when I could) as deeply committed and caring parents often failed to advocate effectively for their children because they didn't have the necessary communication skills (see Lareau, 2000, 2003 for a compelling account of this problem). This gap in civic knowledge and skills thus impacts not just individuals' interactions with government officials or politicians but also their everyday experiences at school and in their communities.

\section{Behavior and Participation}

There has been a fair amount of media coverage of the voting gap based on race, ethnicity, income, and education level. In the presidential election of 2004, for example, Hispanic and Asian voting-age citizens voted at a rate only twothirds that of eligible Whites (approximately 45 versus $67 \%$, respectively) (U.S. Census Bureau, 2005, Table 4a), while people living in families with incomes under $\$ 15,000$ voted at about half the rate of those living in families with incomes over $\$ 75,000$ (45 versus $80 \%$, respectively) (U.S. Census Bureau, 2005, Table 9). 
Likewise, $11 \%$ fewer naturalized versus native-born citizens voted, which is a cause for concern since $20 \%$ of the U.S. population is first- or second-generation immigrant (U.S. Census Bureau, 2005, Table 13; see also DeSipio, 2001).

Despite widespread excitement about Barack Obama's candidacy and media coverage suggesting huge increases in youth and minority turnout, 2008 presidential election voting rates almost exactly replicated the disparities seen in 2004. While 65 to $66 \%$ of White and Black voting-age citizens voted in the 2008 presidential election, for example, barely half of Hispanic, Asian, Native American, or other voting-age citizens did so (McDonald, 2009). The voting gap between native-born and naturalized citizens in 2008 also exactly replicated the results in 2004 (65 versus $54 \%$ ). Similarly, in both 2004 and 2008, voting rates of citizens with less than a high-school diploma persisted at less than $40 \%$, compared with a little over half of citizens' with a high-school diploma choosing to cast their ballot, participation by almost three-quarters of citizens who had attended college, and voting rates of over $80 \%$ of those with post-graduate education (McDonald, 2009). And finally, half of those with an income under $\$ 15,000$ voted, versus $79 \%$ of those with an income over $\$ 100,000$ (U.S. Census Bureau, 2008). It is worth remembering that these voting rate disparities persisted despite the extreme competitiveness of the Democratic primary election and the historic nature of the 2008 presidential campaign.

Significant behavior disparities also persist beyond voting. Reliable analyses of political participation, as measured by membership in political parties, campaign donations, campaign volunteering, participation in protests, contacting an elected official, and so forth, show vast disparities linked with class, education, and race. People who earn over $\$ 75,000$ annually are politically active at up to six times the rate of people who earn under $\$ 15,000$, whether measured by working for a campaign, serving on the board of an organization, or participating in protests (Verba, Schlozman, \& Brady, 1995, p. 190, Figure 7.2). Broader measures of civic participation-belonging to any group or organization, working on a community problem, volunteering, attending a community meeting, or even just wearing a campaign button or putting a political bumper sticker on one's car-also seem to be highly unequally distributed by educational attainment. The 2008 Civic Health Index, for example, found that $81 \%$ of young adults with no college experience were "not very engaged" civically according to these and similar measures, as compared to $41 \%$ of young adults with some college experience (National Conference on Citizenship, 2008). Latinos, too, are far less involved in all of these activities than Whites or Blacks, and Blacks are more likely to participate in "outsider" activities such as protests rather than "insider" activities such as campaign donations or direct contact with officials (Verba, Schlozman, \& Brady, 1995, chap. 8; Nie, Junn, \& Stehlik-Barry, 1996; see also Wolfinger \& Rosenstone, 1980). Hispanic young adults (ages 18 to 24) in particular have much lower rates of voter registration and community involvement 
than their White and Black peers (Verba, Schlozman, \& Brady, 1995; Lopez, 2003; Lopez, Levine, Both, Kiesa, Kirby, \& Marcelo, 2006, p. 20).

It is important to note that the forecast is not entirely grim. Recent immigration reform efforts, including rallies, marches, and protests surrounding support for the DREAM Act and opposition to the 2006 proposed congressional immigration bill, mobilized significant numbers of Hispanic and first- and secondgeneration immigrant youth and adults. Most likely as a result of these protests, more immigrant youth reported participating in protests in 2006 than native-born youth (Lopez et al., 2006; Seif, this volume). In addition, African American youth and to a lesser extent Asian American youth ages 18 to 29 are in many ways more politically or civically engaged than their White counterparts as measured by the 2006 and 2008 Civic Health surveys (Lopez et al., 2006; National Conference on Citizenship, 2008; see also Marcelo, Lopez, \& Kirby, 2007). This may indicate that the civic participation gap is actually lessening among youth, or at least emphasize that race and ethnicity contribute less than income and education to the civic empowerment gap. However, the data are too recent and context-specific to foster confidence about long-term reductions in the civic behavior gap.

Furthermore, even if the promising trends continue, the civic participation gap remains enormous in the United States as compared to other developed (and even many less-developed) democracies (Torney-Purta \& Amadeo, 2004, pp. 56, $69,88)$. There is a tendency in the United States to normalize the demographic difference in participation rates by explaining it away in the same way many did with the reading or math achievement gap a decade ago: "But of course poor people [or Hispanics, etc.] participate less. They don't have the time or financial resources (or education, knowledge) to participate as wealthier people do." This argument doesn't make sense when one considers, for example, the protests in Argentina a few years ago, when hundreds of thousands of poor and middle-class people took to the streets banging pots and pans and ended up forcing the resignations of their political leaders; they were actually following the example set by piqueteros (picketers) - unemployed workers who started a nationwide movement for social change in the 1990s and have sustained it for over a decade. If unemployed and uneducated citizens in Argentina (as well as other South American democracies) can demonstrate such high levels of civic and political engagement, poor people in the United States could do the same. This is not to argue that socioeconomic differences in political participation are negligible in other countries. Studies of European, Canadian, and Central American voter turnout rates in the 1980s and 1990s demonstrate that those democracies have an average 10 to 12 percentage point difference in voter turn-out between the mostand least-educated citizens - but this is far eclipsed by the United States' 35\% gap (Powell, 1986; Lijphart, 1997, p. 3). Furthermore, the participation gap has not always been a major feature even of American civic and political life (see Montgomery, 1993). In the late nineteenth and early twentieth centuries, 
immigrant incorporation groups, trade unions, fraternal organizations, and political parties regularly mobilized poor, working-class, non-White, and newly immigrant Americans (Skocpol, 1999; Montgomery, 2001, p. 1268ff; Sachar, 1993, pp. 175176; Freeman, 2002), and participation in civic organizations was extremely widespread (Skocpol, Ganz, \& Munson, 2000).

\section{Attitudes}

People's decisions to participate in civic life are at least partly determined by their attitudes: whether they believe that individuals can influence government (political efficacy), that they themselves can influence government (individual efficacy), that one has a duty to participate (civic duty), and that one is part of a civic community (civic identity). All of these pro-civic attitudes are disproportionately correlated with both race/ethnicity and class.

Verba, Schlozman, and Brady show, for example, that individuals' political efficacy increases in direct relationship to their income, with the poorest individuals expressing attitudes almost a full standard deviation lower than the wealthiest; it is also significantly correlated with race/ethnicity, with Latinos at the bottom, African Americans in the middle, and White respondents at the top (Verba, Schlozman, \& Brady, 1995, Table 12.4). Similarly, a study specifically of young Latinos, African Americans, and Whites (ages 15 to 25) shows equivalent significant individual efficacy differences in their confidence that "I can make a difference in solving the problems of my community" (Lake Snell Perry \& Associates \& The Tarrance Group, 2002; Carnegie Corporation of New York \& CIRCLE, 2003; although, see Hunter \& Bowman, 1996; Washington Post, Kaiser Family Foundation, \& Harvard University, 2000; Baldi, Perie, Skidmore, Greenberg, \& Hahn, 2001, for some conflicting research). These efficacy disparities are further reflected in individuals' competing interpretations of controversial political events. A Newsweek poll following Hurricane Katrina, for example, showed that twice as many African Americans versus White Americans (65 versus $31 \%$ ) thought the government responded slowly to the disaster because most of the affected people were African American (Huddy \& Feldman, 2006).

President Obama's election and administration may narrow the efficacy gap, but is not likely to eliminate it, if for no other reason than that the gap is utterly rational. White, middle-class or wealthy, college-educated, and native English-speaking citizens living in relatively high social capital neighborhoods undeniably $d o$ have greater opportunities to influence government or public policy than do non-White, educationally underserved, economically disadvantaged youth and adults living in neighborhoods with limited social and political capital (Jacobs $\&$ Skocpol, 2005; Bartels, 2008). Although unjust and profoundly antidemocratic, this fact remains equally true no matter who is president. The problem, however, is that the efficacy gap may be viciously self-reinforcing, if those who correctly view 
themselves as more able to make a difference become ever more involved while those who question their efficacy withdraw from public civic engagement.

Two other attitudinal components contribute significantly to the civic empowerment gap: namely, individuals' senses of civic identity and civic duty. Dawson has demonstrated in considerable quantitative and qualitative detail the ways in which African Americans' senses of civic membership and responsibility are distinct from non-African Americans' in being focused on the "linked fate" of African Americans as a group (Dawson, 1994, 2001). Immigrant citizens' sense of civic identity is similarly ambiguous. Although their sense of patriotism tends to be as high as or higher than native-born citizens, their sense of themselves as Americans is more tenuous. In interviews I conducted in April 2004 with firstand second-generation Arab-American students, parents, teachers, and community leaders in Dearborn, MI, for example, my interlocutors (most of whom were citizens) consistently referred to "Americans" as "they":

Interviewer: Three of you are American citizens, born in the United States. But you have consistently throughout the interview ... used the term "Americans" not to refer to yourselves but to refer to others. ... [Y] ou talked about Americans as other people. So I'm curious why.

Student: I see what you're trying to get us to say-like we were born here, like, why shouldn't we consider ourselves as regular American people. But I think that we're different because we have to fall back on our parents' background because our parentsthat's what they teach us. That's what our culture is. Like our background from our old country and stuff like that.

This echoes other scholars' findings from New York City.

[Second generation immigrants] used the term American in two different ways. One was to describe themselves as American compared to the culture, values, and behaviors of their parents. ... But they also used "American" to refer to the native white Americans that they encountered at school, the office, or in public places, but whom they knew far better from television and the movies. They saw those "Americans" as part of a different world that would never include them because of their race/ethnicity. Many respondents sidestepped this ambivalent understanding of the meaning of being American by describing themselves as "New Yorkers" (Kasinitz, Mollenkopf, \& Waters, 2002; see also Stepick \& Stepick, 2002).

Similarly ambivalent attitudes and experiences of civic disjuncture have been found among poor, non-White, and immigrant youth (Rubin, 2007; Abu ElHaj, 2008). 
Even if these do demonstrate a significant civic empowerment gap along the four dimensions of civic knowledge, skills, attitudes, and behaviors between non-White, immigrant, and especially low-income citizens, on the one hand, and White, native-born, and especially middle- and high-income citizens, on the other, why should we care? I suggest that anyone who believes in the value of democratic governance should recognize how crucial it is to narrow the gap. Individuals' civic knowledge, skills, and attitudes profoundly influence their civic and political behavior, which is concomitantly central to the strength, stability, and legitimacy of democracy. We saw above that civic knowledge is clearly and directly correlated with higher levels of political participation, expression of democratic values, stable political attitudes, and adoption of "enlightened selfinterest" (Galston, 2001; Delli Carpini \& Keeter, 1996). Individuals' mastery of civic skills is also tied to both their likelihood of civic participation and their effectiveness. "Those who possess civic skills, the set of specific competencies germane to citizen political activity, are more likely to feel confident about exercising those skills in politics and to be effective - or, to use the economist's term, productive - when they do" (Verba, Schlozman, \& Brady, 1995, p. 305).

Participation, of course, matters because democratic governance relies on participatory citizens. The legitimacy, stability, and quality of democratic regimes are all directly dependent on the robust participation of a representative and large cross-section of citizens. Governments that appear to serve the interests of only a narrow segment of the population cease to be viewed as democratic, and cease to inspire the loyalty and commitment of those who feel excluded. This poses a direct threat to both their legitimacy and stability. Political violence by citizens is also tightly linked to feelings of disaffection and alienation (Kinder, 1998, pp. 831-832). Furthermore, democratic deliberations and decisions are likely to be of lower quality if people representing only a fairly narrow range of experiences, interests, and backgrounds are involved. Part of the beauty of democracy, when it functions effectively and inclusively, is its ability to create aggregate wisdom and good judgment from individual citizens' necessarily limited knowledge, skills, and viewpoints. To exclude citizens from this process is to diminish the wisdom that the collectivity may create.

Attitudes matter because they constitute the motivational preconditions for civic engagement. Whether one knows nothing about current events or has an advanced degree in political science, whether one is a shy follower or a brilliant orator and leader, if one doesn't believe that civic and political participation can make a difference, then one is not going to participate. Political efficacy is crucial for motivating civic and political engagement. Attitudes of civic duty or obligation are also important motivators: "Citizens with a strong sense of civic duty are about 6 percentage points more likely to turn out to vote in recent presidential elections than are their otherwise comparable counterparts who do not recognize voting as an obligation of citizenship" (Kinder, 1998, p. 832). Verba, 
Schlozman, and Brady also found that civic obligation was the most important attitudinal predictor for civic activism (Verba, Schlozman, \& Brady, 1995, chap. 4). And finally, identity seems to figure importantly in influencing the character and quality of civic engagement, as political psychologists, philosophers, and others have shown (Damon, 2001, pp. 127, 135; Feinberg, 1998, p. 47).

Above all else, the gaps in knowledge, skills, attitudes, and participation matter because they profoundly diminish the democratic character and quality of the United States.

Generations of Americans have worked to equalize citizen voice across lines of income, race, and gender. Today, however, the voices of American citizens are raised and heard unequally. The privileged participate more than others and are increasingly well organized to press their demands on government. Public officials, in turn, are much more responsive to the privileged than to average citizens and the less affluent. The voices of citizens with lower or moderate incomes are lost on the ears of inattentive government officials, while the advantaged roar with the clarity and consistency that policymakers readily hear and routinely follow (Jacobs \& Skocpol, 2005, p. 1).

Not all of these unequal levels of influence can be attributed to differences in individual levels of knowledge, skills, attitudes, or participation, of course. There are powerful institutional, political, and other factors at work that would likely contribute to the persistence of inegalitarian and undemocratic outcomes even if the gaps explored above were eliminated. The exploding cost of political campaigns and politicians' corresponding dependence upon and attention to wealthy donors provide only one obvious example of the multiple barriers to equal civic empowerment. But it is clear that the civic empowerment gap among individuals is a significant threat to democratic ideals and practice. I suggest that it is important for both the civic and political empowerment of poor, minority, and immigrant individuals, and for the health of the polity as a whole, that we develop means for closing the gap.

\section{De Facto Segregated Minority Schools}

One important battleground for attacking the civic empowerment gap is the network of mostly urban schools that serve a de facto segregated, poor, and minority student population. Fully one-third of Black and Latino students in the United States, and over half of the Black students in the Northeast, attend schools that have a 90 to $100 \%$ minority student population (Orfield \& Lee, 2006; see also Orfield, Eaton, \& The Harvard Project on Desegregation, 1996; Orfield, 2001, Tables 14 and 18). The overwhelming majority of these schools are in urban areas, often central cities. Over half of all schools in the one hundred largest school districts were 81 to $100 \%$ non-White in 2005 to 2006, and one-fifth of 
these districts had a non-White student population above 90\% (Garofano \& Sable, 2008, Table A-8). In practice, therefore, most schools in these districts had a virtually $100 \%$ minority population, often from a single race or ethnicity. Detroit, Baltimore, Atlanta, Memphis, and Washington, DC, have over $80 \%$ black student enrollment; Brownsville (TX), Santa Ana (CA), San Antonio, and El Paso are more than 80 percent Latino; Los Angeles is almost three-quarters Latino while San Francisco is more than half Asian (Garofano \& Sable, 2008, Table A-9). The students in these schools and districts are also generally poor. Half of all students in the 100 largest school districts are eligible for free or reduced-price lunch, and in 21 of these districts, which together serve close to four million students, more than seven out of every ten students are eligible for free or reduced price lunch (Garofano \& Sable, 2008, Table A-9 and A-1). Many of these students thus face "double segregation" by both race/ethnicity and class (Orfield \& Lee, 2007, p. 5).

The number of these schools serving poor, urban, de facto segregated ethnically or racially minority schools is likely to increase in upcoming decades. Orfield and his colleagues have exhaustively documented that schools and school districts in the United States are resegregating, not desegregating (Orfield, Eaton, \& The Harvard Project on Desegregation, 1996; Orfield, 2001; Orfield \& Lee, 2007). This trend will likely accelerate thanks to the Supreme Court's decision in Parents Involved versus Seattle ("Parents Involved," 2007), which invalidated race-conscious school assignment policies designed to promote integrated schools in Seattle, Washington, and Louisville, Kentucky. Furthermore, public pressure for integrated schools has diminished considerably. In a 1998 survey, for example, African American survey respondents joined White respondents in ranking racial diversity second from the bottom of their preferred characteristics for a good school (Public Agenda Foundation, 1998); this stands in stark contrast to Blacks' attitudes in the 1970s and 1980s, when integration was a high priority not only in principle but also in practice. Integration is viewed by many as "yesterday's struggle" (Loury, 1997), with greater importance being placed on students' obtaining an "equal opportunity to learn" (Ladson-Billings, 2004), whether in integrated or segregated settings (Horsford \& McKenzie, 2008; Walker \& Archung, 2003; Shujaa, 1996). African American and Latino political leaders have similarly shifted their focus from integration to equality of opportunity. Leaders of the NAACP, for instance, have held "a formal debate over the virtues of nonsegregated versus black-run schools for black students" (Patterson, 2001, p. 192) and released statements minimizing desegregation concerns (although they did file an amicus brief in support of Seattle's and Louisville's school integration policies). Black mayors in Seattle, Denver, St. Louis, and Cleveland have also led efforts to dismantle desegregation practices (Hochschild \& Scovronick, 2003, pp. 48-49; see also Massey \& Denton, 1993), while a leader of La Raza recently asserted, "Having $100 \%$ of one ethnicity is not a bad thing" (Bracey, 2009, p. 691). As Justice Clarence Thomas wrote in his concurring opinion in the Seattle 
and Louisville cases, rejecting the constitutionality of school integration policies, "It is far from apparent that coerced racial mixing has any educational benefits, much less that integration is necessary to black achievement" ("Parents involved," 2007, p. 15). Some prominent scholars have also questioned the desirability of school integration (see, e.g., Bell, 2004, 1980); in Gloria Ladson-Billings' words, "It would be better to have a 'real Plessy' than to continue with a 'fake Brown"" (Ladson-Billings, 2009). With scholarly, public, and Supreme Court opinions like this, segregated schools will clearly remain a fact of twenty-first century American life.

These schools matter for two other reasons beyond their mere prevalence and staying power. First, Kahne and Middaugh's analysis of several large datasets documents a clear civic opportunity gap between these schools and those that serve wealthier or whiter students, or both:

[A] student's race and academic track, and a school's average socioeconomic status (SES) determines the availability of the school-based civic learning opportunities that promote voting and broader forms of civic engagement. High school students attending higher SES schools, those who are college-bound, and white students get more of these opportunities than low-income students, those not heading to college, and students of color. (Kahne \& Middaugh, 2008, p. 3)

In practice, this means that students in average versus high SES classes are half as likely to report studying how laws are made, barely half as likely to report participating in service activities, and 30\% less likely to report having experiences with debates or panel discussions in their social studies classes (Kahne \& Middaugh, 2008, p. 16). Since these figures derive from a study only of "average" versus high SES classes, they most likely understate the degree of the disparity between truly impoverished schools and students and those that serve a more privileged student body. But Kahne and Middaugh provide more than enough evidence to demonstrate that poor and non-White students are receiving demonstrably less and worse civic education than middle class and wealthy, white students, and that school-level differences are partly to blame.

Second, the civic learning opportunity gap suffered by poor and non-White students especially attending de facto segregated urban schools compounds the civic opportunity gaps they face outside of school. Considerable evidence demonstrates that people living in areas of concentrated poverty are significantly less likely to be engaged civically, and to have opportunities for such civic engagement, than those living in more mixed or affluent communities (AlexAssensoh, 1997; Cohen \& Dawson, 1993; Hart, Atkins, Markey, \& Youniss, 2004). Youth in particular face significant impediments in developing civic identities (Atkins \& Hart, 2003) or acquiring civic knowledge and skills (Hart \& Atkins, 2002) when they grow up in high-poverty urban communities. Since youth 
who are being educated in de facto segregated, non-White, poor urban schools are also almost surely living in de facto segregated, poor urban neighborhoods, this means that students attending these schools are facing a civic opportunity gap in their neighborhoods as well as in their schools (Wilkenfeld, 2009).

One can conclude that a large number of poor, ethnically and racially segregated public schools exist; they educate a substantial percentage of ethnic and racial minority students in the United States; their numbers are likely to increase rather than decrease over the coming years, (U.S. Census Bureau News, 2008); and they provide significantly fewer and lower-quality civic learning opportunities than schools that serve a whiter and wealthier student population. If we care about political stability, democratic legitimacy, and civic equality, then we must care about what gets taught and learned in these schools - not just for the students' sakes but for our own. This is consistent with condemning the phenomenon of de facto segregated schooling as harmful to the students who attend these schools, to the students who don't attend these schools (and who hence are often educated in relatively segregated settings themselves), and to the nation as a whole. There is substantial evidence that the best education for students in a liberal democratic society requires schools that are integratedintegrated ethnically and racially, but also by class, religion, immigration status, and other aspects of family background (Orfield \& Lee, 2007; "Parents Involved," 2007, [Stevens., J, dissenting]; American Educational Research Association, 2006; Levinson \& Levinson, 2003; Blum, 2002; Reich, 2002; Levinson, 1999; Gutmann, 1995, 1987; Macedo, 1990). But these arguments are irrelevant as regards the current existence and likely future expansion of de facto segregated minority schools. These schools pose challenges to U.S. democratic politics today, and the students who attend them hence merit attention now, including an appropriate civic education.

\section{What We Can Do}

Thus far, I have established two things. First, there is a profound civic empowerment gap in the United States that disproportionately muffles the voices of non-White, foreign-born, and especially low-income citizens and amplifies the voices of White, native-born, and especially wealthy citizens. Second, many of these poor, minority citizens attend de facto segregated schools when young. Given the high percentage of young people at the lower end of the gap who attend these schools, these schools' documented contributions to the civic learning opportunity gap, and the obstacles to civic empowerment often posed by segregated, economically impoverished settings, we should pay special attention to how civic educational practices in these schools might be reformed in order to combat the civic empowerment gap. This is not to say that school reform will be sufficient. Numerous changes need to be made across multiple sectors of society, including: consistent, same-day voter registration laws; early and expanded voting 
opportunities; nonpartisan redistricting boards to increase the number of contested elections; political and economic policies that reduce as opposed to increase economic inequality; increased investment in low-income communities; massive reform of the school-to-prison pipeline in poor and minority communities; improved and expanded social service provision; greater challenges to institutional racism; and immigration reform. (See Macedo, Alex-Assensoh, Berry, et al., 2005 , for a careful examination of the ways in which electoral, municipal, and voluntary sector policies and practices often impede the quantity, quality, and equality of civic engagement in the United States.) But schools should not be left out of the picture, as they also have an important role to play. My purpose in the rest of this chapter is to provide some constructive suggestions for how de facto segregated schools, in particular, can help reduce the civic empowerment gap, and hence help promote true civic and political equality for all Americans.

I recommend five essential reforms specifically for de facto segregated, poor and minority, urban public schools.

\section{Commit to improving urban schools and reducing the drop-out rate,} which reaches nearly $50 \%$ in some urban districts. Calls for urban school reform may seem simultaneously banal and absurdly idealistic: Who doesn't support the massive overhaul and improvement of urban schools in the United States in the early twenty-first century, and who has robust confidence in such an overhaul bearing significant fruit? Yet it is a need that nonetheless bears repeating. Both the civic empowerment gap and the quality gap between many impoverished urban versus wealthier suburban schools remind us that our society is inegalitarian and anti-democratic in some fundamental ways. If urban schools were better, and if more students stayed in higher-quality schools and graduated, the civic empowerment gap would narrow. Furthermore, higher quality urban education resulting in higher educational attainment among students who attended those schools would likely have a direct effect on these students' civic empowerment, since education is the single most highly correlated variable with civic knowledge, civic skills, democratic civic attitudes, and active civic engagement (Nie, Junn, \& Stehlik-Barry, 1996; Galston, 2003).

2. Restore civic education to the curriculum. The decline in the number, range, and frequency of civics courses offered in U.S. elementary and high schools must be reversed. There is ample evidence that civic education improves civic outcomes (Damon, 2001; Delli Carpini \& Keeter, 1996; Galston, 2001; Carnegie Corporation of New York \& CIRCLE, 2003; Niemi \& Junn, 1998; Torney-Purta, 2002; Torney-Purta, Hahn, \& Amadeo, 2001; Kahne \& Middaugh, 2008), but resources devoted to it have dropped markedly over the past 30 or 40 yearsespecially in schools serving minority students. In the 1960s, students regularly took as many as three relevant courses in high school, including civics, democracy, and government; now students tend to take only one-governmentand that only in the 12th grade (Carnegie Corporation of New York \& CIRCLE, 
2003, p. 14; Niemi \& Junn, 1998), by which point many poor and minority students have already dropped out. Close to $10 \%$ of America's poorest students drop out of high school each year; students from the bottom economic quintile are four-and-a-half times more likely than their peers from families in the top $20 \%$ of the income distribution to decide to drop out of high school (Laird, Kienzl, DeBell, \& Chapman, 2007, p. 4 and Figure 1). Likewise, barely $70 \%$ of Hispanic student youth overall, and only $58 \%$ of immigrant Hispanic youth, have graduated from high school by age 24, in comparison with $85 \%$ of Blacks, $93 \%$ of Whites, and $96 \%$ of Asians (Laird, Kienzl, DeBell, \& Chapman, 2007, Table 9). If civic education is offered to students only in 12th grade, therefore, then in effect it is disproportionately provided to wealthier, whiter, and native-born citizens.

Furthermore, it is absurd to think that by offering civic education only a few times over the course of a child's education, we will reliably enable and encourage students to become active, engaged citizens. There is a reason that we require students to take English and math every semester of every year of elementary and secondary school: Mastery takes time and practice. Hence we expect students to engage in on-going, consistently reinforced learning and coaching with regard to these essential disciplines and practices. If we want students to become masterful citizens, then the same expectations should apply. If we want to narrow the civic empowerment gap, especially by increasing poor, minority, and immigrant students' civic knowledge and skills, then civic education must begin in elementary schools and be a regular part of education kindergarten through 12th grade (and beyond).

\section{Reform history education in order to help students construct empowering civic narratives that simultaneously cohere with their lived experiences and impel them to civic and political action. When we think about} how to eliminate the civic empowerment gap, we need to take seriously what students bring with them into the classroom from their lived experience; from the stories and messages they hear from family members, friends, and neighbors; and from various media sources. Students aren't empty vessels waiting to be filled with appropriate civic attitudes and knowledge; rather, they come into the classroom having already at least partially constructed their own understandings of their civic identity, of their membership in or exclusion from the polity, and even of history's significance and meaning for their own lives. (See Epstein, 1997, 2001, 2009; Wineburg, 2001; VanSledright, 2002; Barton \& Levstik, 2004, for further evidence of this attitude and approach.)

When teachers and schools attempt to address the civic empowerment gap, therefore, they need to engage with students' constructions of history, civic membership, political legitimacy, and power relations. They need to recognize that students construct meaning independent of - and hence often in conflict with - the meanings specified by curricula, textbooks, teachers, or other educational authorities (Torney-Purta, 2002; Haste, 2004; Torney-Purta, Barber, \& Wilkenfeld, 2007). Educators must therefore overtly and intentionally engage 
with students' beliefs, attitudes, and narrative schema, which means adjusting instruction from school to school, class to class, and student to student. At the same time, educators must maintain a vision of desirable civic outcomes (including desirable civic and political knowledge, skills, attitudes, and behaviors) that goes beyond what students enter with. Engagement with students' constructed narratives, in other words, does not mean straightforwardly validating them, since the civic empowerment gap cannot be solved simply by reinforcing students' beliefs, attitudes, and differences. Rather, educators need to help students to construct more empowering civic narratives: ones that are truthful but not self-defeating, and that incorporate individuals' and communities' lived experiences while simultaneously justifying and reinforcing a sense of personal and political efficacy, civic membership, and civic duty.

This approach requires a massive change in how and why history is taught in this country, and especially in most urban schools. History education would have to be co-constructed with students, as opposed to delivered as a set of truths to be memorized. Textbooks would need to be used "only [as] reference works," as Diane Ravitch correctly recommends (Ravitch, 2003, p. 156), rather than as primary - let alone sole - sources of knowledge and historical understanding. American history courses, currently taught as a "moderately triumphalist" story of inevitable historical progress toward grand American ideals (Gibbon, 2002; see also Damon, 2001; Ravitch, 2003; Schlesinger, 1993; Stotsky, 2004; Avery \& Simmons, 2000), would need to be radically rethought. There would also need to be a shift away from teaching history as a story of individual, larger-than-life heroes to teaching history as a story of collective action by ordinary people (Levinson, 2009). Even the most profound civic changes, led by the greatest and most extraordinary of human beings, are usually brought about by the collective work of ordinary people working together: of "men and women obscure in their labour," as President Obama put it in his Inaugural Address (Obama, 2009). I suggest that one possible model might be found in a civic counter-narrative fostered by many historically segregated African American institutions, including de jure and de facto segregated schools, Freedom Schools, historically Black colleges and universities, and Black churches. These institutions have often taught a civically empowering historical counter-narrative centered on themes of struggle, obligation, and opportunity. With some imagination and flexibility, teachers and students in other settings could expand upon and incorporate these historical narratives in ways that promote their own civic and political engagement.

Although part of the work of helping students construct empowering civic narratives has to be done in a historical context, recognizing how students interpret the past in relationship to their possible roles in the present, other work needs to be done in a contemporary context. This means changing students' civic and political present by involving them in guided experiential civic learning and other civically empowering pedagogies. Thus, I suggest the following. 


\section{Provide students frequent opportunities to engage in empowering civic}

practices: discussion of meaningful, contemporary, and controversial issues; simulations, role plays, and mock trials; classroom and school elections; group collaboration on problems that address community concerns and attitudes in a way that enables students to demonstrate their local knowledge and expertise; and participation in guided experiential civic learning in which they actually do civics, not just read about it, including via public policy involvement, youth organizing, participatory action research, or other mechanisms. Civic education needs to become a living part of the school, and it must enable students regularly to exercise their democratic rights and responsibilities. In other words, civic education at its heart must be about active participation, not passive observation. In order to increase students' political and personal efficacy, in particular, and to change students' minds about the value of civic and political engagement more generally, we need to find ways of giving them positive, real-world, civic and political experiences.

What would this look like in practice? Guided experiential civic learning can take a variety of forms, including activities within classrooms and schools as well as those beyond school walls. Students could serve on the school site council, governing board, or diversity committee. They could invite local community leaders to come visit the school and then interview them in small cooperative groups about their accomplishments, the challenges they face, and what motivates them to keep on working for what they believe in. After conducting a "constituent survey" of their peers, students could work together as a class to develop and implement a strategy to improve an aspect of their school. Students could debate current events and then write a letter expressing their opinions to an elected representative or government official. They could participate in a mock trial, conduct a voter registration drive in the school parking lot or before PTA meetings, or create a WebQuest about a policy issue that matters to them. An ambitious teacher could encourage students to research a public policy issue and then make a presentation to local officials, or attend a city council meeting as advocates for their position. Even more ambitiously, a teacher may serve as a facilitator for participatory youth action research projects, in which youth research and act upon problems that they themselves identify and define. Closer to home, students could elect class officers who will collaborate with the teacher on planning field trips and other special activities; or, they could as a class deliberate about and vote on issues including due dates for major projects, the order in which to read class novels, or the consequences for minor disciplinary infractions. Numerous examples, analyses, and evaluations of such approaches are available in the research literature (e.g., Weis \& Fine, 2000; DarlingHammond, French, \& Garcia-Lopez, 2002; Westheimer \& Kahne, 2002; Kahne \& Westheimer, 2003; Noguera, Ginwright, \& Cammarota, 2006; Apple \& Beane, 2007; Schultz, 2008; Cammarota \& Fine, 2008; Delgado \& Staples, 2008; Hess, 2009 ) and from practitioners and civic education organizations. (See 
www.campaignforthecivicmissionofschools.org for information about and links to over 100 well-vetted curricula, programs, and organizations.)

It's important to note that although these examples range from very simple and straightforward to quite ambitious, they all intentionally build on collective and policy-oriented action. None represent such piecemeal approaches as donating cans to a homeless shelter or spending a morning visiting elderly people in a nursing home. Although both of these activities are noble and may be worthwhile, they don't foster the kind of attention to systemic issues that is important. Nor do they help students recognize the power of their community and of joining together to effect change. Emphasis on communal action is especially important when teaching poor, historically disenfranchised youth who tend to live in poor, historically disenfranchised communities, since collective action is one of the most effective ways to reduce (even if not entirely eliminate) their power differential (Alinsky, 1971).

Research uniformly supports the efficacy of these kinds of active civic learning approaches (Hahn, 1998; Amadeo, Torney-Purta, Lehmann, Husfeldt, \& Nikolova, 2002; Westheimer \& Kahne, 2002; Kahne \& Westheimer, 2003; Carnegie Corporation of New York \& CIRCLE, 2003; Kirshner, 2007; Rogers, Morrell, \& Enyedy, 2007; Torney-Purta, Barber, \& Wilkenfeld, 2007; Hess, 2009). Done well, guided experiential civic education helps students learn and apply a broad range of civic knowledge, develop a number of civic skills, embrace positive civic attitudes, and practice important civic behaviors. It promotes an active, explicitly political conception of citizenship. It can help students make contacts with adults and role models in the community, as well as help the participating organizations and institutions themselves. Guided experiential civic education can motivate students to become civically engaged in the future by contributing to their sense of empowerment and agency, connecting them to adults and peers who model civically engaged behavior, and enabling them to use their knowledge and skills to achieve concrete results. Guided experiential civic learning may also reinforce (or generate) adults' sense of connection to and responsibility and respect for the younger generation, including toward children and young adults who live and are being educated in communities different from those adults' own. These are all extremely important civic outcomes.

\section{Finally, we need to provide powerful civic learning and engagement} opportunities for urban teachers, so they can develop these domains of knowledge, skills, attitudes, and habits of participation themselves. Teachers in de facto segregated, poor urban schools are often as civically disempowered as their students. Urban teachers work in institutions that are often incredibly bureaucratic, that discourage and even sometimes punish autonomous decision-making, and that foster a culture of compliance rather than collaboration. They are chronically underfunded and are buffeted by political and partisan swings in ways that tend to make long-term institutional improvement unlikely. These are not the conditions for building civic skills or civic efficacy among adults, let alone youth. Civic 
education reform to combat the civic empowerment gap is necessary not just for students, therefore, but for teachers as well.

As schools put these reforms into place, they will provide students and teachers with a set of powerful civic experiences that are likely to increase their sense of personal and political efficacy and trust, and hence to inspire their acquisition of civic knowledge and skills as well as continued productive participation. In doing so, schools will also help strengthen local communities, both via the direct work that students accomplish and by building a new generation of mobilized, empowered adults. Reducing the civic empowerment gap also strengthens democracy. It broadens government's representativeness, increases its responsiveness to diverse individuals and communities, and thereby also reinforces its political legitimacy in the eyes of historically disenfranchised community members. It strengthens schools, as students turn their attention to solving problems collaboratively as opposed to fighting against the system or just checking out. And finally, it promotes civic and political equality and fairnessideals that are central to our American democracy. These are goals all schools can and should embrace. 


\section{References}

Abu El-Haj, T. R. (2008). 'I was born here, but my home, it's not here': Educating for democratic citizenship in an era of transnational migration and global conflict. Harvard Educational Review, 77(3), 285-316.

Alex-Assensoh, Y. (1997). Race, concentrated poverty, social isolation, and political behavior. Urban Affairs Review, 33(2), 209-227.

Alinsky, S. D. (1971). Rules for radicals: A pragmatic primer for realistic radicals. New York: Vintage Books.

Amadeo, J.-A., Torney-Purta, J., Lehmann, R., Husfeldt, V., \& Nikolova, R. (2002). Civic knowledge and engagement: An IEA study of upper secondary students in sixteen countries, executive summary. Amsterdam: IEA.

American Educational Research Association (2006). Amicus curiae 10. Retrieved from http://www.aera.net/uploadedFiles/News_Media/AERA_Amicus_Brief.pdf

Apple, M. W., \& Beane, J. A. (Eds.). (2007). Democratic schools: Lessons in powerful education. Portsmouth, $\mathrm{NH}$ : Heinemann.

APSA Task Force on Inequality and American Democracy (2004). American democracy in an age of rising inequality. Perspectives on Politics, 2(4), 651-689.

Atkins, R., \& Hart, D. (2003). Neighborhoods, adults, and the development of civic identity in urban youth. Applied Developmental Science, 7(3), 156-164.

Avery, P. G., \& Simmons, A. M. (2000). Civic life as conveyed in United States civics and history textbooks. International Journal of Social Education, 15(2), 105-130.

Ayers, W., \& Ford, P. (1996). City kids, city teachers. New York: The New Press.

Baldi, S., Perie, M., Skidmore, D., Greenberg, E., \& Hahn, C. (2001). What democracy means to ninth-graders: U.S. Results from the international IEA civic education study (No. NCES 2001-096). Washington, DC: U.S. Department of Education and National Center for Education Statistics.

Bartels, L. M. (2008). Unequal democracy: The political economy of the new gilded age. New York: Russell Sage Foundation.

Barton, K. C., \& Levstik, L. S. (2004). Teaching history for the common good. Mahwah, NJ: Lawrence Erlbaum Associates.

Bell, D. A. (2004). Silent covenants: Brown v. Board of Education and the unfulfilled hopes for racial reform. Oxford: Oxford University Press.

Bell, D. A. (Ed.). (1980). Shades of Brown: New perspectives on school desegregation. New York: Teachers College Press.

Blum, L. (2002). The promise of racial integration in multicultural age. In S. Macedo \& Y. Tamir (Eds.), Moral and political education. New York: New York University Press.

Bracey, G. W. (2009). Our resegregated schools. Phi Delta Kappan, 90(9), 691-692. 
Cammarota, J., \& Fine, M. (2008). Revolutionizing education: Youth participatory action research in motion. New York: Routledge.

Carnegie Corporation of New York, \& CIRCLE (2003). The civic mission of schools. New York: Carnegie Corporation of New York and CIRCLE.

Cohen, C. J., \& Dawson, M. C. (1993). Neighborhood poverty and African American politics. American Political Science Review, 87(2), 286-302.

Damon, W. (2001). To not fade away: Restoring civil identity among the young. In D. Ravitch \& J. P. Viteritti (Eds.), Making good citizens (pp. 123-141). New Haven and London: Yale University Press.

Darling-Hammond, L., French, J., \& Garcia-Lopez, S. P. (Eds.). (2002). Learning to teach for social justice. New York: Teachers College Press.

Dawson, M. C. (1994). Behind the mule: Race and class in African-American politics. Princeton: Princeton University Press.

Dawson, M. C. (2001). Black visions: The roots of contemporary African-American political ideologies. Chicago: Chicago University Press.

Delgado, M., \& Staples, L. (2008). Youth-led community organizing: Theory and action. Oxford: Oxford University Press.

Delli Carpini, M., \& Keeter, S. (1996). What Americans know about politics and why it matters. New Haven: Yale University Press.

DeSipio, L. (2001). Building America, one person at a time: Naturalization and political behavior of the naturalized in contemporary American politics. In G. Gerstle \& J. Mollenkopf (Eds.), E pluribus unum? Contemporary and historical perspectives on immigrant political incorporation (pp. 67-106). New York: Russell Sage Foundation.

Epstein, T. (1997). Sociocultural approaches to young people's historical understanding. Social Education, 61, 28-31.

Epstein, T. (2001). Racial identity and young people's perspectives on social education. Theory into Practice, 40(1), 42-47.

Epstein, T. (2009). Interpreting national history: Race, identity, and pedagogy in classrooms and communities. New York: Routledge.

Feinberg, W. (1998). Common schools/ uncommon identities. New Haven: Yale University Press.

Freeman, J. B. (2002). Red New York. Monthly Review, 54(3), 36-42.

Galston, W. A. (2001). Political knowledge, political engagement, and civic education. Annual Reviews Political Science, 4, 217-234.

Galston, W. A. (2003). Civic education and political participation. Phi Delta Kappan, 85(1), 29-33.

Garofano, A., \& Sable, J. (2008). Characteristics of the 100 largest public elementary and secondary school districts in the United States: 2005-06 (No. NCES 2008- 
339). Washington, DC: National Center for Education Statistics, Institute of Education Sciences, U.S. Department of Education. Retrieved from http://nces.ed.gov/pubs2008/100_largest_0506

Gibbon, P. (2002, 2005). Panel discussion: Why is U.S. History still a mystery to our children? October 1, 2002. Retrieved from http://www.aei.org/events/filter.,eventID.131/transcript.asp

Grossman, L. (2009). Iran protests: Twitter, the medium of the movement. Time Magazine. Retrieved from http://www.time.com/time/world/article/0,8599,1905125,00.html

Gutmann, A. (1987). Democratic education. Princeton: Princeton University Press.

Gutmann, A. (1995). Civic education and social diversity. Ethics, 105(3), 557-579.

Hahn, C. L. (1998). Becoming political. Albany: State University of New York Press.

Hart, D., \& Atkins, R. (2002). Civic competence in urban youth. Applied Developmental Science, 6(4), 227-236.

Hart, D., Atkins, R., Markey, P., \& Youniss, J. (2004). Youth bulges in communities: The effects of age structure on adolescent civic knowledge and civic participation. Psychological Science, 15(9), 591-597.

Haste, H. (2004). Constructing the citizen. Political Psychology, 25(3), 413-439.

Hess, D. E. (2009). Controversy in the classroom: The democratic power of discussion. New York: Routledge.

Hochschild, J., \& Scovronick, N. (2003). The American dream and the public schools. New York and Oxford: Oxford University Press.

Horsford, S. D., \& McKenzie, K. B. (2008). 'Sometimes I feel like the problems started with desegregation': Exploring black superintendent perspectives on desegregation policy. International Journal of Qualitative Studies in Education, 21(5), 443-455.

Huddy, L., \& Feldman, S. (2006). Worlds apart: Blacks and whites react to hurricane Katrina. Du Bois Review, 3(1), 1-17.

Hunter, J. D., \& Bowman, C. (1996). The state of disunion: 1996 survey of American political culture, executive summary. Charlottesville, VA: The Post-Modernity Project, University of Virginia. Retrieved from http://religionanddemocracy.lib.virginia.edu/programs/survey/pubinfo.html

IES: National Center for Education Statistics (2007). NAEP data explorer. Retrieved from http://nces.ed.gov/nationsreportcard/nde/

Jacobs, L. R., \& Skocpol, T. (Eds.). (2005). Inequality and American democracy: What we know and what we need to learn. New York: Russell Sage Foundation.

Kahne, J., \& Middaugh, E. (2008). Democracy for some: The civic opportunity gap in high school. College Park, MD: CIRCLE. Retrieved from http://www.civicyouth.org/PopUps/WorkingPapers/WP59Kahne.pdf 
Kahne, J., \& Westheimer, J. (2003). Teaching democracy: What schools need to do. Phi Delta Kappan, 85(1), 34-40, 57-66.

Kasinitz, P., Mollenkopf, J., \& Waters, M. C. (2002). Becoming Americans/becoming New Yorkers: The experience of assimilation in a majority minority city. International Migration Review, 36(4), 1020-1036.

Kinder, D. R. (1998). Opinion and action in the realm of politics. In D. T. Gilbert, S. T. Fiske, \& G. Lindzey (Eds.), The handbook of social psychology (4th ed., pp. 778867). Boston: McGraw-Hill.

Kirshner, B. (2007). Introduction: Youth activism as a context for learning and development. American Behavioral Scientist, 51(3), 367-379.

Ladson-Billings, G. (2004). Landing on the wrong note: The price we paid for Brown. Educational Researcher, 33(7), 3-13.

Ladson-Billings, G. (2009). Inching toward equity. The Forum for Education and Democracy (2009, June 9). Retrieved from http://www.forumforeducation.org/node/477

Laird, J., Kienzl, G., DeBell, M., \& Chapman, C. (2007). Dropout rates in the United States: 2005 (NCES 2007-059). Washington, DC: U.S. Department of Education and the National Center for Education Statistics. Retrieved from http://nces.ed.gov/pubs2007/2007059.pdf

Lake Snell Perry \& Associates, \& The Tarrance Group (2002). Short-term impacts, longterm opportunities: The political and civic engagement of young people in America: CIRCLE and The Center for Democracy \& Citizenship and the Partnership for Trust in Government at the Council of Excellence in Government.

Lareau, A. (2000). Home advantage: Social class and parental intervention in elementary education. Lanham, MD: Rowman \& Littlefield.

Lareau, A. (2003). Unequal childhoods: Class, race, and family life. Berkeley: University of California Press.

Levinson, M. (1999). The demands of liberal education. Oxford: Oxford University Press.

Levinson, M. (2009). 'Let us now praise. . .?' Rethinking heroes and role models in an egalitarian age. In Y. Raley \& G. Preyer (Eds.), Living in a global world: New essays in the philosophy of education (pp. 129-161). Oxford: Routledge.

Levinson, M., \& Levinson, S. (2003). 'Getting religion': Religion, diversity, and community in public and private schools. In A. Wolfe (Ed.), School choice: The moral debate (pp. 104-125). Princeton: Princeton University Press.

Lijphart, A. (1997). Unequal participation: Democracy's unresolved dilemma. American Political Science Review, 91(1), 1-14.

Lopez, M. H. (2003). Electoral engagement among Latino youth. College Park, MD: CIRCLE. Retrieved from 
http://www.civicyouth.org/PopUps/Electoral\%20\%20Engagement\%20Among\%2 OLatino\%20Youth.pdf

Lopez, M. H., Levine, P., Both, D., Kiesa, A., Kirby, E., \& Marcelo, K. (2006). The 2006 civic and political health of the nation: A detailed look at how youth participate in politics and communities. College Park, MD: CIRCLE.

Loury, G. C. (1997, April 23). Integration has had its day. The New York Times, p. A23. Retrieved from http://www.nytimes.com/1997/04/23/opinion/integration-has-hadits-day.html?scp=1\&sq=\&st=nyt

Lutkus, A. D., Weiss, A. R., Campbell, J. R., Mazzeo, J., \& Lazer, S. (1999). NAEP 1998 civics report card for the nation (No. NCES 2000-457). Washington, DC: U.S. Department of Education, Office of Educational Research and Improvement, and National Center for Education Statistics.

Macedo, S. (1990). Liberal virtues. Oxford: Oxford University Press.

Macedo, S., Alex-Assensoh, Y., Berry, J. M., Brintnall, M., Campbell, D. E., Fraga, L. R., et al. (2005). Democracy at risk: How political choices undermine citizen participation and what we can do about it. Washington, DC: Brookings Institution Press.

Marcelo, K. B., Lopez, M. H., \& Kirby, E. H. (2007). Civic engagement among minority youth (Fact Sheet). College Park, MD: CIRCLE.

Massey, D. S., \& Denton, N. A. (1993). American apartheid: Segregation and the making of the underclass. Cambridge, MA: Harvard University Press.

McDonald, M. (2009). 2008 current population survey. (2009, April 6). Retrieved from http://elections.gmu.edu/CPS_2008.html

Montgomery, D. (1993). Citizen worker: The experience of workers in the United States with democracy and the free market during the nineteenth century. Cambridge: Cambridge University Press.

Montgomery, D. (2001). Presidential address: Racism, immigrants, and political reform. The Journal of American History, 87(4), 1253-1274.

National Conference on Citizenship (2008). 2008 Civic health index: Beyond the vote. Retrieved from http://www.ncoc.net/download.php?file=2kccfl36\&ext=pdf\&name=2008\%20Civi c\%20Health\%20Index

Nie, N. H., Junn, J., \& Stehlik-Barry, K. (1996). Education and democratic citizenship in America. Chicago: Chicago University Press.

Niemi, R. G., \& Junn, J. (1998). Civic education: What makes students learn. New Haven: Yale University Press.

Niemi, R. G., \& Sanders, M. S. (2004). Assessing student performance in civics: The NAEP 1998 civics assessment. Theory and Research in Social Education, 32(3), 326-348. 
Noguera, P., Ginwright, S. A., \& Cammarota, J. (2006). Beyond resistance! Youth activism and community change: New democratic possibilities for practice and policy for America's youth. New York: Routledge.

Obama, B. (2009, January 20Inaugural address. Retrieved from (via podcast) http://www.telegraph.co.uk/news/worldnews/northamerica/usa/barackobama/429 8722/President-Barack-Obamas-inaugural-address-speech-in-full.html

Orfield, G. (2001). Schools more separate: Consequences of a decade of resegregation. Cambridge, MA: The Civil Rights Project, Harvard University.

Orfield, G., Eaton, S., \& The Harvard Project on Desegregation (1996). Dismantling desegregation: The quiet reversal of Brown v. Board of Education. New York: The New Press.

Orfield, G., \& Lee, C. (2006). Racial transformation and the changing nature of segregation. Cambridge, MA: The Civil Rights Project at Harvard University.

Orfield, G., \& Lee, C. (2007). Historic reversals, accelerating resegregation, and the need for new integration strategies. Los Angeles: Civil Rights Project/Proyecto Derechos Civiles, UCLA. Retrieved from http://www.civilrightsproject.ucla.edu/research/deseg/reversals_reseg_need.pdf

Parents Involved in Community Schools vs. Seattle School District No. 1, et. al. (05-908) and Meredith, Crystal (next friend for Mcdonald, Joshua) v. Jefferson county Bd. of Education, et al. (05-915), 5511 (Supreme Court 2007).

Patterson, J. T. (2001). Brown v. Board of Education: A civil rights milestone and its troubled legacy. New York: Oxford University Press.

Powell, G. B., Jr. (1986). American voter turnout in comparative perspective. American Political Science Review, 80(1), 17-43.

Public Agenda Foundation. (1998). Time to move on. New York: Public Agenda Foundation.

Ravitch, D. (2003). The language police: How pressure groups restrict what students learn. New York: Alfred A. Knopf.

Reich, R. (2002). Bridging liberalism and multiculturalism in American education. Chicago: University of Chicago Press.

Rogers, J., Morrell, E., \& Enyedy, N. (2007). Studying the struggle: Contexts for learning and identity development for urban youth. American Behavioral Scientist, 51(3), 419-443.

Rosenzweig, R., \& Thelen, D. (1998). The presence of the past: Popular uses of history in American life. New York: Columbia University Press.

Rubin, B. C. (2007). 'There's still not justice': Youth civic identity development amid distinct school and community contexts. Teachers College Record, 109(2), 449481.

Sachar, H. (1993). A history of the Jews in America. New York: Vintage.

Schlesinger, A., Jr. (1993). The disuniting of America. New York: Norton. 
Schultz, B. D. (2008). Spectacular things happen along the way: Lessons from an urban classroom. New York: Teachers College Press.

Scott, J. C. (1985). Weapons of the weak: Everyday forms of peasant resistance. New Haven: Yale University Press.

Shujaa, M. J. (1996). Beyond desegregation: The politics of quality in African American schooling. Thousand Oaks, CA: Corwin.

Skocpol, T. (1999). How Americans became civic. In T. Skocpol \& M. P. Fiorina (Eds.), Civic engagement in American democracy (pp. 27-80). Washington, DC: Brookings.

Skocpol, T., Ganz, M., \& Munson, Z. (2000). A nation of organizers: The institutional origins of civic voluntarism in the United States. American Political Science Review, 94(3), 527-546.

Stepick, A., \& Stepick, C. D. (2002). Becoming American, constructing ethnicity: Immigrant youth and civic engagement. Applied Developmental Science, 6(4), $246-257$.

Stotsky, S. (2004). The stealth curriculum: Manipulating America's history teachers. Washington, DC: Thomas B. Fordham Foundation. Retrieved from http://www.edexcellence.net/doc/StealthCurriculum\%5BFINAL\%5D04-0104.pdf

The Pew Research Center for the People and the Press (2007, April 15). What Americans know: 1989-2007. Public knowledge of current affairs little changed by news and information revolutions. Retrieved from http://peoplepress.org/reports/pdf/319.pdf

Torney-Purta, J. (2002). The school's role in developing civic engagement: A study of adolescents in twenty-eight countries. Applied Developmental Science, 6(4), 202211.

Torney-Purta, J., Barber, C. H., \& Wilkenfeld, B. (2007). Latino adolescents' civic development in the United States: Research results from the IEA civic education study. Journal of Youth and Adolescence, 36, 111-125.

Torney-Purta, J., Hahn, C. L., \& Amadeo, J.-A. M. (2001). Principles of subject-specific instruction in education for citizenship. In J. Brophy (Ed.), Subject-specific instructional methods and activities (Vol. 8, pp. 373-410). New York and London: JAI Press.

U.S. Census Bureau (2005, May 25). Voting and registration in the election of November 2004. Retrieved from http://www.census.gov/population/socdemo/voting/cps2004.html

U.S. Census Bureau (2008). 2008 Current population survey voting and registration supplement. Retrieved from U.S. Census Bureau: http://www.census.gov/cps/

U.S. Census Bureau News (2008). An older and more diverse nation by midcentury (No. CB08-123). Washington, DC: U.S. Census Bureau. Retrieved from 
http://www.census.gov/Press-

Release/www/releases/archives/population/012496.html

U.S. Department of Education, Institute of Education Sciences, National Center for Education Statistics, \& National Assessment of Educational Progress (NAEP) (2007). Average scale scores with percentages for civics, grade 8, race/ethnicity used in NAEP reports after 2001 [sdrace] x natl school lunch prog eligibility (3 categories) [slunch3]: By jurisdiction, 2006 (NAEP data explorer). NAEP 2006 Civics Assessment. Retrieved from http://nces.ed.gov/nationsreportcard/nde/viewresults.asp?pid=4-2-8-CIVNational---10-SDRACE,SLUNCH3-20063--CR-MN,RP-2-1-1--1-0--2-3--0--1

VanSledright, B. (2002). Confronting history's interpretive paradox while teaching fifth graders to investigate the past. American Educational Research Journal, 39(4), 1089-1115.

Verba, S., Schlozman, K. L., \& Brady, H. E. (1995). Voice and equality: Civic voluntarism in American politics. Cambridge, MA: Harvard University Press.

Walker, V. S., \& Archung, K. N. (2003). The segregated schooling of blacks in the southern United States and South Africa. Comparative Education Review, 47, 2140.

Washington Post, Kaiser Family Foundation, \& Harvard University. (2000). Washington Post/Kaiser Family Foundation/Harvard University national survey on Latinos in America (No. 3023). Washington, DC.

Weis, L., \& Fine, M. (2000). Construction sites: Excavating race, class, and gender among urban youth. New York: Teachers College Press.

Westheimer, J., \& Kahne, J. (2002). Educating for democracy. In R. Hayduck \& K. Mattson (Eds.), Democracy's moment: Reforming the American political system for the 21st century (pp. 91-107). Boulder: Rowman \& Littlefield.

Westheimer, J., \& Kahne, J. (2004). What kind of citizen? The politics of educating for democracy. American Educational Research Journal, 41(2), 237-269.

will.i.am (Producer). (2008, July 30) Yes we can. Retrieved from (via podcast) http://www.youtube.com/watch?v=jjXyqcx-mYY

Wilkenfeld, B. (2009). Does context matter? How the family, peer, school and neighborhood contexts relate to adolescents' civic engagement (CIRCLE Working Paper 64). Medford, MA: Tufts University, CIRCLE.

Williams, M. (2003). Citizenship as identity, citizenship as shared fate, and the functions of multicultural education. In K. McDonough \& W. Feinberg (Eds.), Citizenship and education in liberal-democratic societies: Teaching for cosmopolitan values and collective identities (pp. 208-247). Oxford: Oxford University Press.

Wineburg, S. S. (2001). Historical thinking and other unnatural acts: Charting the future of teaching the past. Philadelphia: Temple University Press.

Wolfinger, R. E., \& Rosenstone, S. J. (1980). Who votes? New Haven: Yale University Press. 
Zukin, C., Keeter, S., Andolina, M. W., Jenkins, K., \& Delli Carpini, M. X. (2006). A new engagement? Political participation, civic life, and the changing American citizen. Oxford: Oxford University Press. 